\title{
Remembering Tom MacArthur and David Graddol
}

\author{
A tribute to two past editors of English Today
}

I write with great professional fondness for Tom MacArthur and David Graddol. There can have been few more excited younger scholars of English than myself in the early 1980 s to come across a sample copy that was doing the rounds in the English department of the University of Durban-Westville of a new popular journal called English Today. It followed a magazine format rather like the History Today that one could find on sale in bookstores and even supermarkets (in some countries anyway). I lapped it all up and eagerly took a personal subscription. A few years later I was surprised to get an invitation from the editor, Tom himself, to contribute an overview on South African English. And to be offered a small compensation for my time. In my enthusiasm I sent off two articles, adding one on South African Indian English. (I cannot remember if I was paid for the second unsolicited piece!). That was the start of an enduring relation with English Today, and it was gratifying to see David Crystal pick up on both those articles in his Encyclopedia of the English Language, also a CUP production. I got to meet Tom in the late 1980s when he gave a talk to the Education faculty at the University of Cape Town. He told me a bit about himself and his teaching stint in India. I was very much taken by this mild and gentle scholar who had quietly advanced the new field of World Englishes. His book The English Languages remains an early classic of the field. I only met Tom twice since, once at a conference and then at a handover meeting for the journal with David Graddol, Kingsley Bolton and myself at Cambridge in 2007. We assured him that we would remain true to the spirit of the journal, in its popular and international outlook - while introducing a small peer-reviewed section. The journal and Tom MacArthur were after all - synonymous up till then. It is a promise that we kept, and our term of co-editorship (2008 to 2012) served to show just how hard Tom had worked behind the scenes all those years. It took three of us to fill his shoes, if I may be allowed a slightly ungainly idiom.

David Graddol is someone whose work I had read and appreciated greatly, especially the book Gender Voices that he had co-written with Joan Swann. I later met him at a typically vast Sociolinguistics Symposium in Reading or Cardiff, but only got to know him as a person during our co-editorship of English Today. Although he described himself as an applied linguist, I realised there was immense community of interest between my socio-cum-contact linguistics and his applied linguistics. David was a very busy man, in great demand as a speaker, often on behalf of the British Council. Yet he never took a chauvinistic stance on English. I recall his great support for an Indian English for India, rather than a British version for all. In his 'futurology of language' David frankly assumed that there'd be a dip in the star of English in favour of Spanish and especially Chinese some day. David was a great talker.

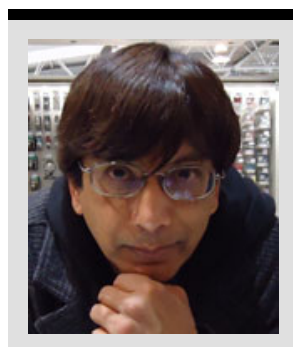

RAJEND MESTHRIE is Emeritus Professor of Linguistics at the University of Cape Town. He was head of the Linguistics Section (1998-2009), and currently holds an NRF research chair in migration, language, and social change. He was President of the Linguistics Society of Southern Africa (2002-9), a co-editor of English Today (2008-2012) and President of the International Congress of Linguists (2013-2018). Amongst his book publications are Language in South Africa (ed., 2002), World Englishes (with Rakesh Bhatt 2008) A Dictionary of South African Indian English (2010) and A Handbook of Sociolinguistics (ed., 2011). 
I fondly remember an occasion when we were both invited speakers at Magdeburg in the former East Germany. And talking long into the night over more than a few beers. I remember David telling me about his three young children - triplets - and the manoeuvres necessary to coordinate their activities. Crossing the street for parents with mobile triplets, for example, was not to be taken lightly, David had counselled. Our co-editorship of English Today was an enjoyable and collegial one, though we all had restrictions on our time. I sometimes wondered if David spent more time in the air than on the ground, so much in demand was he.

My condolences to the families of these two great scholars and colleagues. May they rest in peace knowing that their travails on behalf of the journal are greatly appreciated.

Rajend Mesthrie 